\title{
SEVEN NEW SPECIES OF FISH OF THE ORDER MALACOPTERYGII.
}

\author{
By W. W. Welsh, ${ }^{1}$ \\ Scientific Assistant, United States Bureau of Fisheries.
}

The following descriptions of seven new Malacopterygian fishes have been taken wholly from the unpublished notes of Mr. W. W. Welsh, formerly scientific assistant, United States Bureau of Fisheries, whose most unfortunate demise has placed this work of salvage on me, as the one who was most recently collaborating with Mr. Welsh in the study of fishes.

All illustrations, except that of Aristostomias tittmanni, were prepared under the personal supervision of Mr. Welsh. That of Aristostomias tittmanni was made by Mrs. E. B. Decker, under the direction of Mr. S. F. Hildebrand. Those of Eustomias proximus and bigelowi were drawn by Mr. T. Van de Bogert, and the remainder are from my own pen. Mr. S. F. Hildebrand supplied the footnotes to the description of Aristostomias tittmanni and Eustomias enbarbatus.

C. M. Breder, Jr.

\section{Family GONOSTOMIDAE.}

Gonostomidae Goode and Bean, Oceanic Ichthyology, 1896, p. 97.

\section{Genus DIPLOPHIS.}

Diplophas Gunther, Journ. Mus. Godeffroy, vol. 2, 1873, p. 104.

DIPLOPHOS MOOREI, new species.

Three examples taken by the Bache, two, 43 and $33 \mathrm{~mm}$. in length, at Station 10196, in the northeast Providence Channel, and one, $39 \mathrm{~mm}$. long, at Station 10202, 5 miles west from Gun Cay, in the Straits of Florida. The first two were taken at the surface, the third in a haul at 75 to 0 meters.

This species differs markedly from known forms, in the shorter and deeper body, much lower anal count, and lesser number of photophores.

Dorsal, 12; caudal, 20; anal, 38; ventrals, 8; pectorals, 9.

${ }^{1}$ Compiled and edited posthumously by C. M. Breder, jr., fisheries expert, United States Bureau of Fisheries.

No. 2449.-Proceedings U. S. National museum, Vol. 62. Art. 3. 
Head 5.24 (5.62 in length), compressed, acute, the upper and lower profiles equally oblique; body long, compressed throughout its length; greatest depth at pectoral, 7.86; eye 6.9 in head, circular, lateral; snout 4.93, pointed; mouth large, lower jaw projecting; maxillary 1.53, extending about $1 \frac{1}{2}$ eye diameters beyond vertical from posterior margin of eye, broadened posteriorly; jaws with teeth of moderate size; a few small teeth on vomer; palatines toothless; pseudobranchiae absent; interorbital 5.72, convex; body covered with large cycloid scales, 65 in the lateral line.

Light organs as follows: On the head, one small suborbital; two small black organs on cheek, one above end of maxilliary, the other midway between this and center of pupil; three opercular organs, two on the anterior border of preopercle, the upper on a level with center of eye, the lower at angle of mouth, the third on subopercle slightly above level of pectoral base; a small organ on mandible below and slightly in advance of suborbital; distal end of mandible glandular and apparently luminous; on body, three rows, the upper on lateral line, of 66 small, round photophores, the last of the series on base of caudal rays; second row slightly above level of pectoral, of 48 photophores,

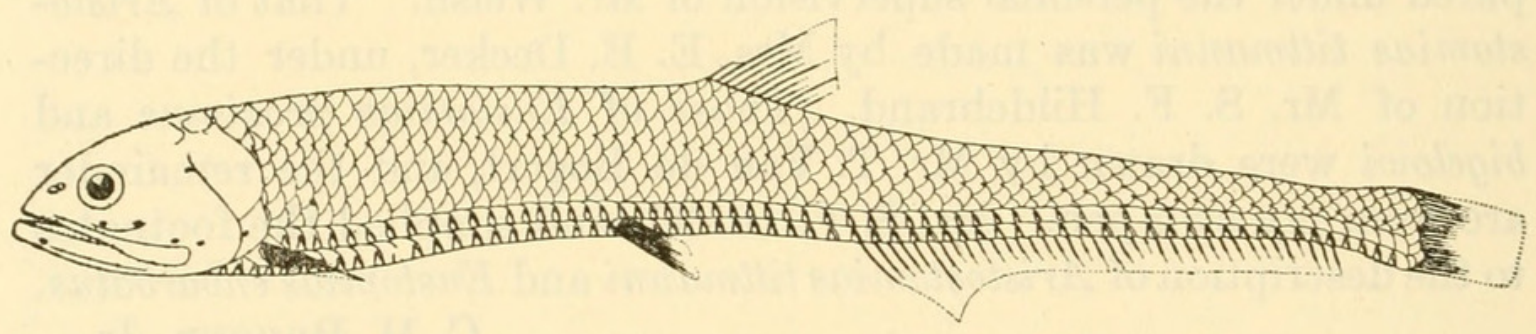

Fig. 1.-Diplophos MOOREI, NEW SPECIES.

2 before pectoral, 18 between pectoral and ventral, 13 between ventral and anal, and 15 extending along base of anal to above $23 \mathrm{~d}$ ray; lower row, on branchiostegals 11 , on isthmus to pectoral 13, pectoral to ventral 17 , ventral to anal 12 , anal to caudal 29 , no gap in this series on caudal peduncle.

Dorsal entirely in advance of anal, its origin in the middle of body length; distance from tip of snout to origin of dorsal 2, to anal 1.74, to ventral 2.41 .

Color in alcohol, head and body clove-brown, the scales edged with darker, cheeks and maxilliary pale, punctulated with brown, mandible yellow at tip; dorsal and anal rays slightly pigmented at base; caudal finely punctulated with brown; ventrals and pectorals unpigmented.

Type.-Cat. No. 84293 , U.S.N.M., $39 \mathrm{~mm}$. long, taken in a townet at Station 10202, in the Gulf Stream, 5 miles west from Gun Cay, at a depth of from 75 to 0 meters.

(moorei, named for Dr. H. F. Moore, Deputy Commissioner United States Bureau of Fisheries.) 
eye diameters behind vertical from posterior margin 'of eye; barbel long, filamentous, simple, ending in a smooth. ovoid knob, its length 1.56 in length without caudal; teeth in both jaws in a single row, of unequal length; in the upper jaw two pairs of long, hollow canines, barbed at tip, followed by five pairs of much smaller teeth, recurved at tip; these are followed by 12 pairs of small straight recumbent teeth; in the lower jaw two pairs of large and five pairs of smaller canines, bladelike and barbed at tip, the first two pairs fitting in grooves on side of snout when mouth is closed; each of the larger fangs appears to have one or more rudimentary fangs at its base, and a minute pore at the tip, opening by a duct into the cavity of the tooth; tongue with two groups of strong retrorse teeth; palatines with four small teeth on each side; vomer toothless; interorbital space 4 ; body scaleless.

A white, ovoid light organ lying in a slitlike socket behind and below eye; a yellow, elongated suborbital organ lying within orbit at basal margin of eye; two rows of small photophores on each side of body ventrally, the upper row consisting of 6 linear groups from pectoral to ventral, $4,3,3,3,3,4$, then a group of 3 and 8 single, more or less equidistant, to vertical from origin of anal, where the row ends in a group of 4 ; ventral row with 6 clustered groups of 2 to 4 each from pectoral to ventral, then 5 linear groups of from 2 to 4 each to above origin of anal; a single row of 11 photophores over base of anal to end of caudal peduncle.

Dorsal origin very slightly behind that of anal, the bases of both fins elevated anteriorly; distance from tip of snout to origin of dorsal, 1.23 ; to anal, 1.27 ; to ventral, 1.70 ; caudal, 2.28 in head, its lower lobe the longer; ventrals, 1.71 in head, behind middle of body, the rays filamentous at tip; pectorals, 1.85 in head, filamentous.

Color in alcohol, head and body very dark sooty brown, almost black, finely sprinkled with minute white granulations; dorsal and anal black basally for about the first 8 or 9 rays; caudal unpigmented; ventral rays spotted with black; pectorals unpigmented; suborbital organ yellow; postorbital organ white; barbel white, with a series of minute black dots, bulb at tip of barbel yellowish.

Type.-Cat. No. 84290, U.S.N.M., $46 \mathrm{~mm}$. long, taken with a townet at Station 10161 about 115 miles east from Cape Hatteras, at a depth of from 100 to 0 meters.

(tittmanni, named for Dr. O. H. Tittmann, former Superintendent of the United States Coast and Geodetic Survey, who authorized the use of the Bache for the South Atlantic expedition.) 


\section{Genus EUSTOMIAS Vaillant.}

Eustomias Varllant, Travailleur et Talisman, 1888, p. 112.

\section{EUSTOMIAS PROXIMUS, new species.}

This species is very close to E. obscurus Vaillant, from which it differs in the larger number of dorsal and anal rays, the character of the ventrals and pectorals, and the color of the skin.

Six examples, as follows:

Station 10169 C, 270 miles southeast from Cape Hatteras, 50 to 0 meters, 2 examples, 83 and $80 \mathrm{~mm}$.

Station 10180, 30 miles southwest from Bermuda (type)), 75 to 0 meters, 1 example, $132 \mathrm{~mm}$.

Station 10186, 270 miles southwest from Bermuda, 85 to 0 meters, 1 example, $75 \mathrm{~mm}$.

Station 10209, 40 miles north from Little Bahama Bank, 100 to 0 meters, 1 example, $98 \mathrm{~mm}$.

Station 10211, 90 miles north from Great Abaco Island, 100 to 0 meters, 1 example, $101 \mathrm{~mm}$.

Dorsal, 29; caudal, 19; anal, 43; ventral, 7; pectoral, 3.

Head 8.33 ( 8.80 in total length), compressed, its breadth 2.5 in its length, profile concave; body long, cylindrical, compressed poste-

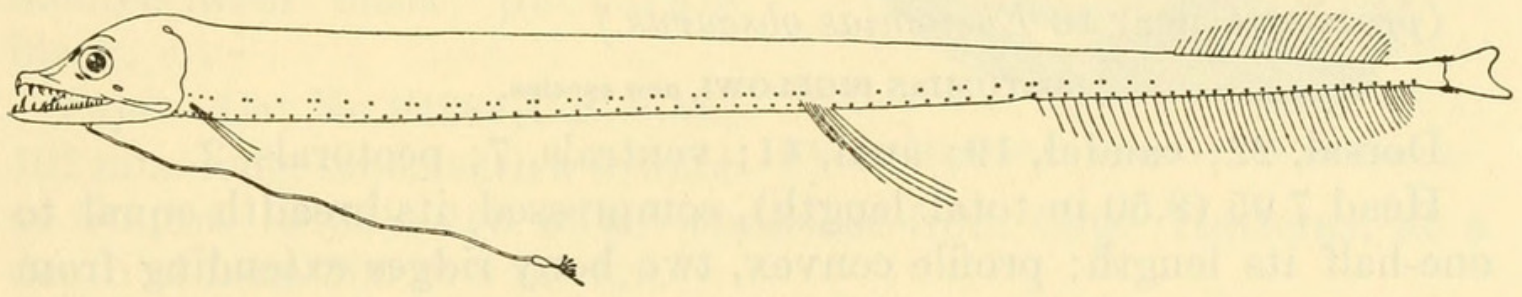

Fig. 3.-Eustomias Proximus, NEW SPECIES.

riorly; greatest depth 18 (18.9 in total length); eye 5, lateral, circular; snout, 2.73, pointed; mouth large, lower jaw projecting; maxillary 1.15 , extending $1 \frac{2}{3}$ eye diameters beyond vertical from posterior margin of eye; barbel long, filamentous, its shaft unpigmented, terminating in a dark-colored suboblong bulb, slightly constricted mesially, from the distal end of which arises a short stalk bearing six filaments; of these, one is about as long as the bulb, the others about one-third shorter; each filament bears at its tip a club-shaped, dark-colored bulb; teeth in both jaws in a single row, canine, recurved, of unequ

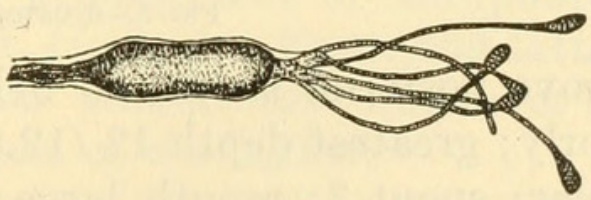

Fig. 4.-EUStomias PRoximus, TIP OF BARBEL.

length, the largest in the upper jaw being the first, second, third, and seventh, in the lower jaw the second, third, and sixth; tongue with three pairs of strong recurved teeth; vomer and palatines toothless; interorbital 3.75, concave; body scaleless.

A small elongated luminous area close to maxillary behind vertical from posterior margin of eye, a similar area beneath lower anterior 
margin of eye, and a minute one of similar shape in lower margin of eye; what appears to be a crescent-shaped luminous area on upper margin of eye; two rows of photophores on sides of body ventrally, the upper row spaced singly and in pairs as follows: Gill opening to ventrals, $1,1,1,2,1,2,1,1,2,2,2,2,2,2,2,2,1,2,1,2,20$ groups; ventrals to anal, $1,1,1,2,1,2,6$ groups; anal to end of series, 1, 2, 1, 1, 4 groups; lower row spaced singly, hyoid arch, 9; isthmus to pectoral, 7 ; pectoral to ventral, 33 ; ventral to anal, 11 ; anal to caudal, 26.

Dorsal origin over 13 th anal ray, its termination over 38 th anal ray; distance from tip of snout to origin of dorsal 1.22, to anal 1.39, to ventral 1.81, to pectoral 8.18; length of ventrals equal to that of head, the two outer rays short, but not standing in a detached group; pectorals 1.75 in head, the rays separate, each with a bladelike membrane extending to tip.

Color in alcohol, head and body dark metallic bronze, thickly covered with minute black punctulations; all fins unpigmented.

Type.-Cat. No. 84285, U.S.N.M., $132 \mathrm{~mm}$. in length, taken with a townet at Station 10180, 30 miles southwest from Bermuda, at a depth of from 75 to 0 meters.

(proximus, near to Eustomias obscurus.)

\section{EUSTOMIAS BIGELOWI, new species.}

Dorsal, 22; caudal, 19; anal, 41; ventrals, 7 ; pectorals, 2.

Head 7.95 ( 8.50 in total length), compressed, its breadth equal to one-half its length; profile convex, two bony ridges extending from

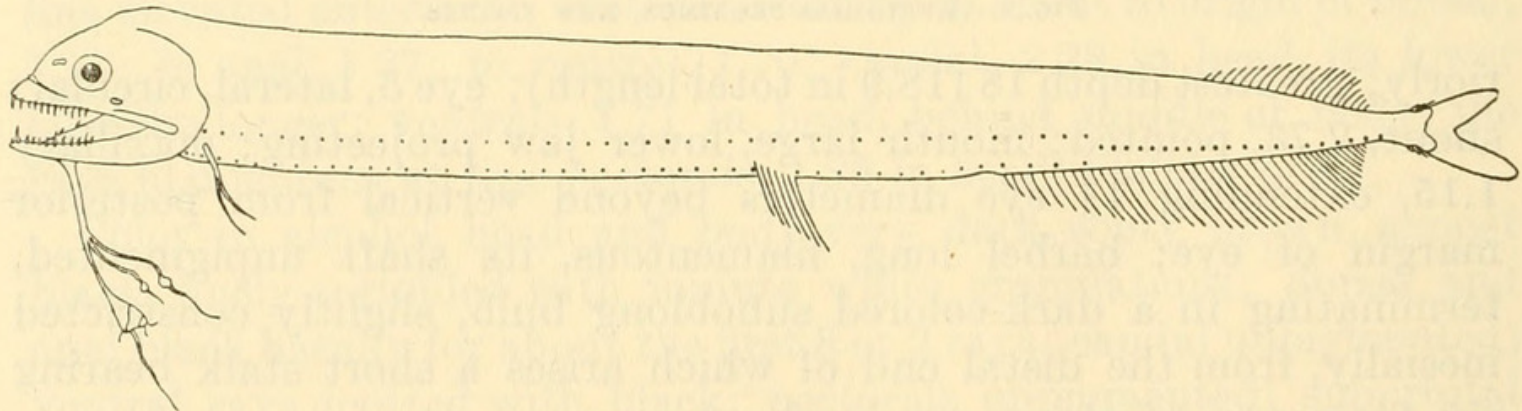

Fig. 5.-Eustomias bigelowi, NeW SPecies.

above posterior nostril to behind eye; body long, compressed posteriorly; greatest depth 12 (12.8 in total length); eye 4.80, lateral, circular; snout 3 ; mouth large, jaws equal; maxillary 1.17 , extending about 2 eye diameters behind vertical from posterior margin of eye; barbel short, stout, 7.35 in length without caudal, club shaped, three filaments arising about midway in its length, a subconical organ at its tip, from which arise three long and four short filaments; teeth in both jaws in a single row, canine, of unequal length, their tips recurved, the largest in the upper jaw being the first, fourth, tenth, and fifteenth; tongue with three pairs of strong recurved fangs, vomer and palatines toothless; interobital 4, convex; body scaleless. 
A small triangular luminous area close to maxillary behind vertical from posterior margin of eye; two rows of small, circular, nearly equidistant photophores along side of body ventrally, extending to about the 6 th anal ray; from this point to the caudal peduncle a single intermediate row of somewhat larger photophores; upper row, gill opening to ventrals, 29 ; ventrals to anal, 10 ; along anal, 4 ; lower row, isthmus to pectorals, 9 ; pectorals to ventrals, 29 ; ventrals to anal, 10 ; along anal, 4; intermediate row along anal to caudal peduncle, 21.

Dorsal origin over 15 th anal ray; distance from tip of snout to origin of dorsal 1.15 , to anal 1.33 , to ventral 1.74 , to pectoral 7.35 ; ventrals 1.6 in head, the rays not divided into two groups; pectorals 1.5 in head, the rays filamentous, closely united for a short distance at base.

Color in alcohol, body and head velvety black, with minute white granulations, these most abundant along lower row of photophores; barbel black, its conical tip and filaments white; dorsal and anal nearly colorless, their rays pigmented basally, the last 10 banded with black at segments; ventrals colorless, the rays evenly pigmented with black; pectorals black.

Type.-Cat.No.84284,U.S.N.M., $102 \mathrm{~mm}$. long, taken with a townet

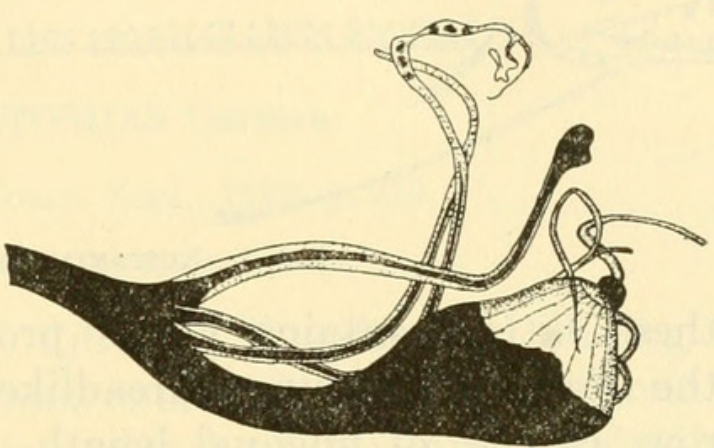

Fig. 6.-Eustomias bigelowi, Tip of Barbel. at Station $10163 \frac{1}{2}, 170$ miles southeast from Cape Hatteras, at a depth of from 500 to 0 meters.

One other example, $88 \mathrm{~mm}$. long, anal count 42 , taken in a townet at Station 10162, 120 miles east-southeast from Cape Hatteras, at a depth of from 150 to 0 meters.

(bigelowi, named for Dr. H. B. Bigelow, of the Cambridge Museum of Comparative Zoology.)

\section{EUSTOMIAS ENBARBATUS, new species.}

This species approaches E. obscurus Vaillant and E. proximus, but differs from them in the number and arrangement of the photophores, in which it closely resembles E. bigelowi. From the latter it differs in the number of anal rays, the number and character of the pectoral rays, and the length and form of the barbel. ${ }^{4}$

4 The author has mentioned the close relationship of his species, Eustomias enbarbatus, and $\boldsymbol{E}$. obscurus Vaillant, calling attention to the difference in the arrangement of the photophores. A comparison of the type of E. enbarbatus with the drawing and description of the type of E. obscurus has revealed a few other differences worthy of note for the convenience of the student.

$a$. The ventral fins in E. obscurus are divided into two parts, the upper division consisting of three short rays and the lower of four long rays. These fins are undivided in E. enbarbatus.

$b$. The head in E. obscurus is not notably elevated and the profile is little concave over the snout and only slightly convex from the head to the nape. In E. enbarbatus, as shown in the drawing, the head is much elevated, the profile is concave over the snout and strongly convex over the head

c. A very great difference is evident in the detail structure of the barbel. The bulbs at the end of these organs are different in shape and the tentacles attached thereto are also very different. For the structure of those of E. enbarbatus refer to figure 8. Those of E. obscurus are seven in number, all originating from the distal end of the large bulb, and each tentacle in turn ending in a small bulb. 
Dorsal, 23; caudal, 19; anal, 35; ventrals, 7; pectorals, 3.

Head 7.1 (7.63 in total length), compressed, its profile oblique, its breadth equal to one-third its length; body long, compressed; greatest depth 12.8 (13.8 in total length); eye 5.12, lateral, circular; snout 3 ; mouth large, lower jaw projecting; maxillary 1.20 , extending about 2 eye diameters beyond vertical from posterior margin of eye; barbel long, filamentous, an ovoid bulb at tip; near the base of this bulb arises a long filament containing at intervals yellowish ovoid bodies; from the distal portion of the bulb arise five short filaments, four of which are simple, two of them containing ovoid bodies; the fifth terminates in an ovoid body from which spring two longer filaments, tridentlike, both of which bifurcate; each of

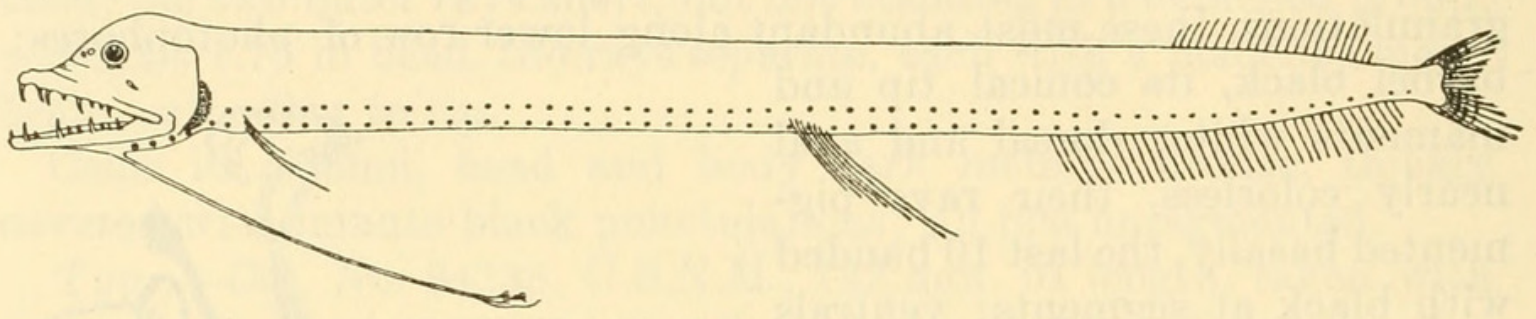

Fig. 7.-Eustomias enbarbatus, NEW Species.

these latter contains in its proximal half several yellow bodies, the distal half being threadlike; teeth in both jaws in a single row, canine, of unequal length, their tips somewhat recurved, the largest in the upper jaw being the first, second, and fifth, in the lower jaw the second, fourth, and seventh; tongue with three pairs

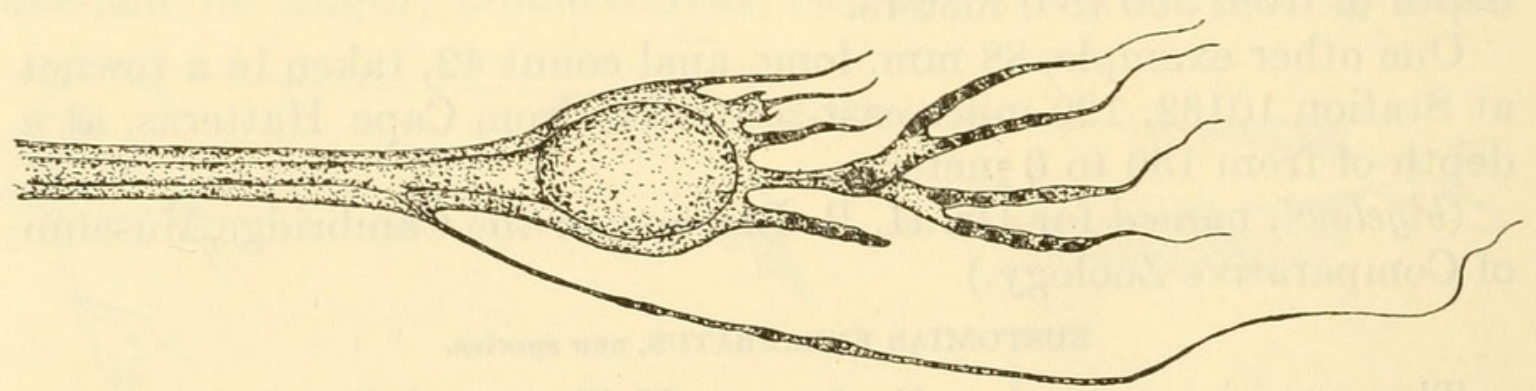

Fig. 8.-Eustomias enbarbatus, tip of barbel.

of long recurved teeth; vomer and palatines toothless; interorbital 4.5 ; body scaleless.

A small oval luminous area close to maxillary behind eye; two rows of small, circular, nearly equidistant photophores on sides of body ventrally, the upper row extending to end of anal, the lower to 5 th anal ray, 27 in each row from pectorals to ventrals.

Dorsal origin over 13 th ray of anal, its termimation over $32 \mathrm{~d}$ ray; distance from tip of snout to origin of dorsal 1.14, to anal 1.33, to ventrals 1.68 , to pectorals 5.81 ; ventrals 1.28 in head, the two outer rays short, but the rays not divided into two groups; pectorals 1.8 in head, the rays apparently filamentous, with a narrow membrane on both sides of each ray, not united at base. 
Color in alcohol, body and head velvety black with minute white granulations, these most abundant along the lower line of photophores; barbel white, its core punctulated with black, bulb at tip and bodies in filaments yellow; vertical fins unpigmented, excepting the last few rays of anal and outer rays of caudal, which are banded with black at the segments basally; ventral and pectoral rays slightly pigmented with black.

Type.-Cat. No. 84282, U.S.N.M., $69 \mathrm{~mm}$. long, taken with a townet at Station 10173, 185 miles west from Bermuda, at a depth of from 100 to 0 meters.

One other example, $60 \mathrm{~mm}$. long, taken at Station 10192, 220 miles northeast from Great Abaco Island, at a depth of from 1,000 to 0 meters. This example has a barbel of the same type, but developed to a lesser degree.

(enbarbatus, calling attention to the remarkable barbel.)

\section{Genus DACTYLOSTOMIAS Garman.}

Dactylostomias Garman, Mem. Mus. Comp. Zool., 1899, p. 279.

DACTYLOSTOMIAS DIGITATUS, new species.

Close to D. ater A. Brauer, but differing therefrom in having a much larger eye, lower dorsal and anal counts, higher pectoral count, and the different character of the suborbital photophore. Only the type taken.

Station 10171, 255 miles west from Bermuda, 75 to 0 meters, 1 example, $35 \mathrm{~mm}$.

Dorsal, 14; caudal, 19; anal, 15; ventrals, 9 ; pectorals, 3 to 4 .

Head 5 (5.82 in total length), long, low, its width 2.40 in its length; body somewhat compressed; depth 10 (11.16 in total length); eye

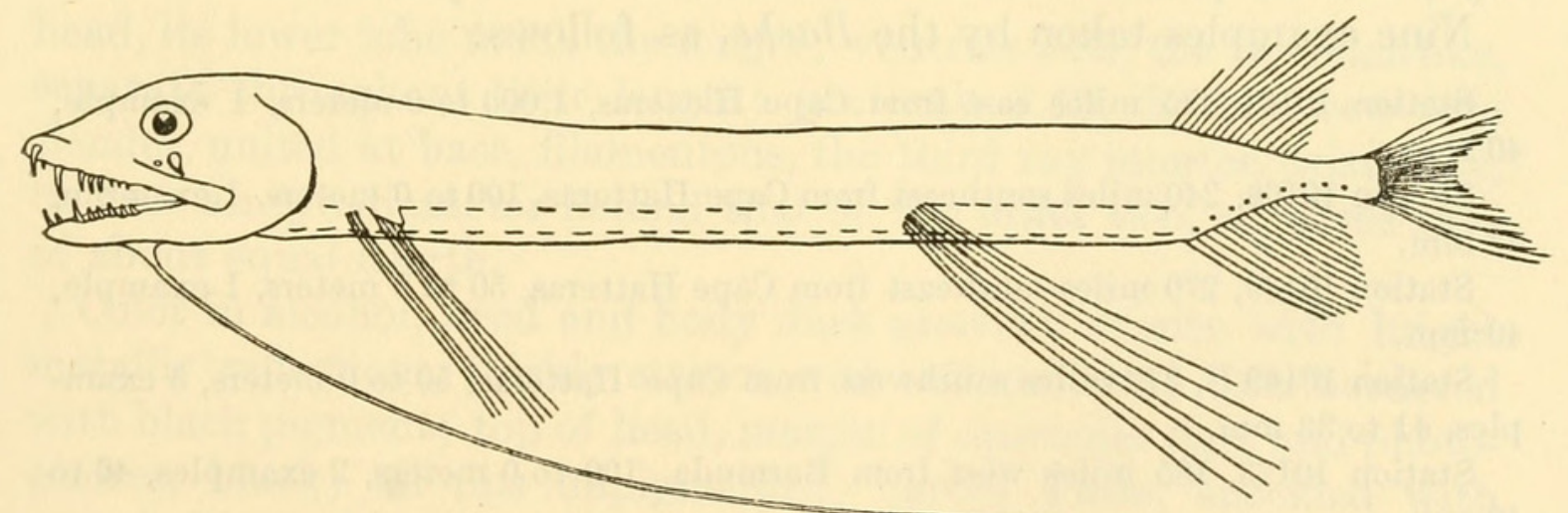

Fig. 9.-Dactylostomlas digitatus, New SPecies.

large, subovate, lateral, its length 4.28 in head, 1.42 in snout; snout acute, projecting; maxillary 1.13, extending about $1 \frac{1}{2}$ eye diameters beyond vertical from posterior margin of eye; barbel long, simple, filamentous; teeth in both jaws in a single row, canine, of unequal length, with recurved tips; first pair in upper jaw set high, protruding through skin of snout; second pair longest, three-fourths diameter of 
eye; seven smaller pairs of canines followed by 16 small recumbent teeth; first pair in lower jaw small, exserted, divergent; second pair longest, followed by eight smaller pairs of canines; tongue with two groups of recurved teeth; four or five teeth on each palatine; vomer toothless; interorbital 3.75 ; body scaleless.

A large ovate luminous organ behind and below eye, a smaller one in advance of this on upper edge of maxillary; two rows of elongated photophores on sides of body ventrally, about 15 in upper row from pectorals to ventrals.

Dorsal origin over that of anal; distance from tip of snout to origin of dorsal 1.20, to ventral 1.87, caudal 1.20 in head, its lower lobe the longer; ventrals 3.75 in length without caudal, the rays hairlike; pectorals 5 in length without caudal, its rays filamentous, the first three closely united at base, a short interspace between these and the next four, which are separate and somewhat swollen at base.

Color in alcohol, head and body metallic bronze, thickly sprinkled with minute white grandular bodies with blackish margins; all fins unpigmented, except the swollen bases of the last four pectoral rays, which are black.

Type.-Cat. No. 84291, U.S.N.M.

(digitatus, fingered.)

\section{Genus TRICHOSTOMIAS Zugmayer.}

Trichostomias Zugmayer, Bull. Ocean. Inst. No. 193, 1911.

TRICHOSTOMIAS METALLICUS, new species.

This species is close to T. vaillianti Zugmayer, from which it differs chiefly in its much smaller eye, higher number of dorsal and anal rays, and the presence of four small teeth on the palatines.

Nine examples taken by the Bache, as follows:

Station 10161, 115 miles east from Cape Hatteras, 1,000 to 0 meters, 1 example, $40 \mathrm{~mm}$.

Station 10166, 240 miles southeast from Cape Hatteras, 100 to 0 meters, 1 example, $42 \mathrm{~mm}$.

Station 10169, 270 miles southeast from Cape Hatteras, 50 to 0 meters, 1 example, $40 \mathrm{~mm}$.

Station 10169 C, 270 miles southwest from Cape Hatteras, 50 to 0 meters, 3 examples, 41 to $33 \mathrm{~mm}$.

Station 10173, 185 miles west from Bermuda, 100 to 0 meters, 2 examples, 46 to $40 \mathrm{~mm}$.

Station 10184, 210 miles south-southwest from Bermuda, 100 to 0 meters, 1 example, $45 \mathrm{~mm}$.

Dorsal, 15 ; caudal, 24 ; anal, 16 ; ventrals, 5 ; pectorals, $2-1$.

Head 4.80 (5.5 in total length), subconic, its width 2.08 , its depth 1.82 in its length, smooth, without ridges; body cylindrical, slightly compressed posteriorly, greatest depth 8.75 (10 in total length); eye minute, circular, 14.6 in head; snout acute, projecting, 2.43 ; mouth large, 
lower jaw included; maxillary 1.04, extending about 8 eye diameters behind vertical from posterior margin of eye; barbel very long, filamentous, its base directly under eye (apparently incomplete in all the examples, in one of which it is $1 \frac{1}{3}$ times length of body without caudal); teeth in both jaws in a single row, canine, of unequal length, the longer teeth in upper jaw projecting when mouth is closed; tongue with two groups of strong retrorse teeth; palatines with two small teeth each; vomer toothless; interorbital 2.65, convex; body scaleless.

An ovoid light organ close to maxillary behind vertical from posterior margin of eye, contiguous with which is an oblong organ on upper edge of maxillary; a row of indistinct glandular organs on sides of snout and cheeks; two rows of small, elongated photophores on sides ventrally, about 30 in each from gill opening to anal; a single row of somewhat larger photophores above anal, extending to end of caudal peduncle.

Dorsal origin three rays in advance of that of anal; distance from tip of snout to origin of dorsal 1.16 , to ventral 1.89 , caudal 1.46 in

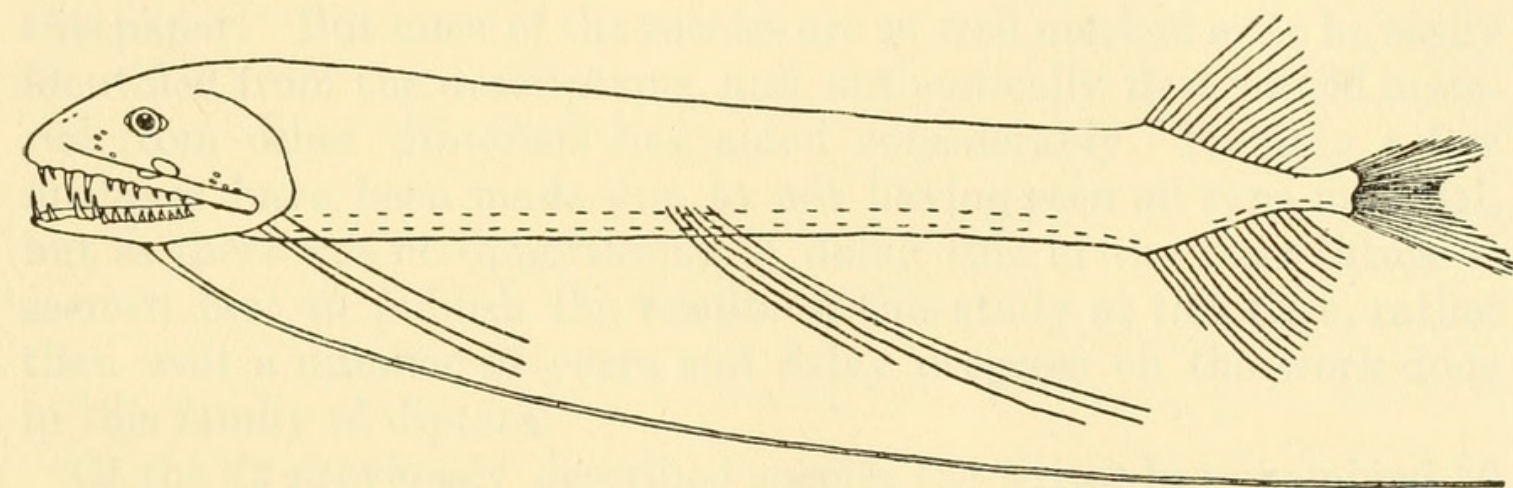

Fig. 10.-TRichostomas metallicus, NEW SPECIES.

head, its lower lobe much the longer; ventrals 2.80 , the rays hairlike, separate throughout their length; pectorals 3.50 , the first two rays slender, united at base, filamentous, the third ray stouter, bristlelike, its base an eye diameter behind that of the other two, all three rays of about equal length.

Color in alcohol, head and body dark greenish bronze with bright metallic reflections, thickly strewn with minute white dots bordered with black pigment; top of head, margin of opercular flap, and photophores, black; all fins unpigmented, barbel white, speckled with minute black chromatophores.

Type.-Cat. No. 84294, U.S.N.M., $40 \mathrm{~mm}$. long, taken in a townet at Station 10169, 270 miles from Cape Hatteras, at a depth of from 50 to 0 meters.

(metallicus, metallic). 


\section{$2 \mathrm{BHL}$ Biodiversity Heritage Library}

Welsh, William W. 1923. "Seven new species of fish of the order Malacopterygii." Proceedings of the United States National Museum 62(2449), 1-11. https://doi.org/10.5479/si.00963801.62-2449.1.

View This Item Online: https://www.biodiversitylibrary.org/item/54629

DOI: https://doi.org/10.5479/si.00963801.62-2449.1

Permalink: https://www.biodiversitylibrary.org/partpdf/53946

\section{Holding Institution}

Smithsonian Libraries

\section{Sponsored by}

Smithsonian

\section{Copyright \& Reuse}

Copyright Status: Public domain. The BHL considers that this work is no longer under copyright protection.

This document was created from content at the Biodiversity Heritage Library, the world's largest open access digital library for biodiversity literature and archives. Visit BHL at https://www.biodiversitylibrary.org. 